\author{
International Journal of Education, \\ Psychology and Counselling (IJEPC) \\ Journal Website: http://ijepc.com/ \\ eISSN: 0128-164X
}

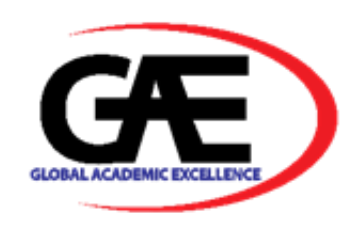

\title{
UNDERGRADUATES' AWARENESS AND OBSTACLES ON ENGLISH LANGUAGE SPEAKING SKILL
}

\author{
Kristina Francis ${ }^{1}$, Bharathi Mutty ${ }^{2}$, Malvin Kaur ${ }^{3}$, Ranjini Kunalan ${ }^{4}$, Nurullashkeen Mohd Anis ${ }^{5}$
}

1 Faculty of Arts \& Social Science, Universiti Tunku Abdul Rahman - Kampar Campus, Malaysia Email: kristinaf@utar.edu.my

2 Faculty of Arts \& Social Science, Universiti Tunku Abdul Rahman - Kampar Campus, Malaysia Email: bharathi@utar.edu.my

3 Faculty of Arts \& Social Science, Universiti Tunku Abdul Rahman - Kampar Campus, Malaysia Email: malvink@utar.edu.my

4 Faculty of Arts \& Social Science, Universiti Tunku Abdul Rahman - Kampar Campus, Malaysia Email: ranjinik@utar.edu.my

5 Faculty of Arts \& Social Science, Universiti Tunku Abdul Rahman - Kampar Campus, Malaysia Email: nurullashkeen@utar.edu.my

\section{Article Info:}

\section{Article history:}

Received date:09.01.2020

Revised date: 23.01 .2020

Accepted date: 03.03.2020

Published date: 15.03 .2020

\section{To cite this document:}

Francis, K., Mutty, B., Kaur, M., Kunalan, R., \& Anis, N. M. (2020). Undergraduates' Awareness and Obstacles on English Language Speaking Skill. International Journal of Education, Psychology and Counseling, 5 (34), 176-188.

DOI: 10.35631/IJEPC.5340014.

\begin{abstract}
:
The English language is a global language as it's the most commonly spoken language in the world by many people around the world. Nevertheless, it is also the language of international business and a necessity for people to speak English if they are to enter a corporate workforce. The English language is significant for employment as organizations are requiring and accepting applicants with good English proficiency. Therefore, it is vital for a student to learn and enhance their English language for a promising future. In learning and becoming proficient in the English Language, students are unable to grasp all of the language skills, especially when it comes to speaking skills. They face multiple challenges in communicating the language in the tertiary level of education as speaking skills is a stepping stone to their career. Thus, future graduates are unaware of the importance of English Language speaking skill as it is one of the necessities to be competitive in a global workforce. This research investigated the undergraduates' perception and challenges on the importance of English language skill and mixed-method was adopted in this study. The results showed that the students understand the importance of English Language speaking skill and also, they have highlighted the challenges of improving their speaking skills.
\end{abstract}




\section{Introduction}

The English language is spotted of being the global language as it is used for various purposes in the world. In Malaysia, the English language was introduced when the country was colonized by the British (Darmi \& Albion, 2015). Malaysia was ruled by British in eighteenth until twentieth century (Thirusanku \& Md Yunus, 2014). The British colonized the Peninsular Malaysia and East Malaysia, administered policies and created multi-ethic and multicultural speech communities (Thirusanku \& Md Yunus, 2014). Thirusanku \& Md Yunus (2014) referred to Platt \& Weber (1980) that the diverse cultures started when the Chinese and Indians were brought into Malaysia. The Malays constituted the highest number of populations in Malaysia, being the dominant ethnic group. As to it, the language was used as a means for business, and the British saw the potential of locals to increase the skills of English language for trading and industry. (Thirusanku \& Md Yunus, 2014). The colonial government formed schools with the medium of instruction was English and the teachers used the Standard British English. As the number of schools increased, the local teachers were natives to the language. English was eventually used in everyday communication among the students. Not only that, English was also used by locals of the different races (Thirusanku \& Md Yunus, 2014). When Malaysia got its independence in 1957, the government declared Malay as the national language. However, English Language was not forgotten. Over time, education policies were changed, and the English language gained credits. Hence, it was accepted as the second language in Malaysia. As changes and evolution happened in the Malaysian education system, English language became one of the compulsory subjects in primary and secondary schools (Ramiza Darmi \& Albion, 2015) in Malaysia. Nevertheless, English language has also become more important in universities within the learning environment and everyday communication (Muhammad Sodbir Hamzah \& Husin Abdullah, n.d).

\section{Background of the Study}

As known, English language has always been an important language in all areas of communication. It is also vital in the global workforce as it contributes significantly to the employment due to the fact organizations requires and accepts applicants with good English proficiency. Therefore, a student learning English language is to enhance their language skill for a promising future. Although of decades of learning the language, students are still unable to grasp the language skills, especially in speaking (Leong \& Ahmadi 2017). They face challenges in communicating in the language especially when they are in the tertiary level of education. This is a crucial issue as they are already in a steppingstone to a career when they are in their tertiary education. The Malaysian Times (2012) found that one of the reasons English is important is because companies prefer their employees to have good English proficiency. It is proven that, most multi-national companies in Malaysia are seeking for those who have English language skills, as it involves communicating at the international level. 


\section{Problem Statement}

During students' school life, students are unaware on the importance of English-speaking skill and for that reason they struggle in their tertiary education. The students are oblivious to the fact in most organizations; one of the requirements to be employed is to be able to speak in English. According to the report from The Star Online (2017) executive director of Malaysia Employers Federation (MEF), Datuk Shamsuddin Bardan said some of them are not capable to construct proper sentences in conversation. A report was found that one of the reason undergraduates are unemployed due to poor English proficiency (Thiagarajan, 2017). Nor Zahidi Alias, known as the chief economist at Malaysian Rating Corp Bhd, stated in World of Buzz, the number of unemployed graduates in Malaysia has increased over the years. According to his published column in The Edge Market, he mentioned 'many of them cannot express themselves adequately at job interviews'. From his experience, employers would hire interviewees based on their ability in communicating effectively. He has also said 'The better they speak, the more attractive they are to potential employers. From this, this is clearly seen that proficiency in speaking the English language is vital and has become a major issue now. Thus, it is important to identify the perceptions and challenges of an individual especially students face in their speaking skills. To support this statement, this study was conducted among undergraduate students to identify their perceptions and challenges they face in English Language speaking skill.

\section{Literature Review}

Leong \& Ahmadi (2017) noted that humans are wired to speak before they learn to read and write. People use most their time interacting orally with. Speaking is the most important skill because it is to perform a conversation. According to Gillis (2013), there are advantages to be able to use words together to convey ideas and feelings. The first advantage would be the ability to inform, persuade and direct. Speaking with strategy and confidence forces the audience to hear and listen to the messages being delivered. The second advantage is the ability to stand out from the rest. Most people are afraid to speak in public, especially in a different language. However, being able to speak fluently and proficiently shows a good first impression. Lastly, is the third advantage on the career enhancement. Employers are at constant search and have always valued well speakers as it is a good outlook for the organization. Pandey \& Pandey (2014) found that having proper English does not necessarily means that a person can construct grammatically correct sentences. It also means that other skills are also significant in polishing such as like presentation, convincing and negotiation skills. Speaking the language comes with fluency and accuracy.

Abbaspour (2016) noted that there have been a few researchers who theorize fluency and accuracy. As an example, Ellis (2009) defined fluency as the capability to use language in real time, emphasizing meanings, possibly drawing on more lexicalized systems (Abbaspour, 2016). Accuracy is the ability to avoid error in performance and to have control in the language (Abbaspour ,2016) The second example by Nation (1991) on defining fluency as the skill to achieve communicative goal avoiding hesitations and pauses that will end in a breakdown of communication (Lan, 1994). Lan (1994) also defines accuracy as the use of correct formation where expressions do not affect the sentence structures, sounds and meanings (Abbaspour, 2016). To sum up, accuracy refers to the ability to produce grammatically correct sentences while fluency refers to the quality of speaking to communicate ideas successfully and be able to produce continuous speech without any difficulties (Abbaspour, 2016). 
Learning the English language comes with its challenges because it is quite a different than learning one's mother tongue. The environment outside of the learning space is one of the factors why students are not encouraged to practice English speaking. This is because majority of people in a society has a bigger influence towards the students in speaking comfortable and a familiar language. Some would look down on those who try to speak in English, which results in students losing their confidence to improve their speaking skills.

Thus, they do not have fluency in English speaking, but these students still want to be accepted by society therefore they revert to their dialect. Thus, these challenges come from internal and external factors. Internal factors refer to the self, whether the students have their own perceptions and are motivated to enhance their English language. The external factors are referred to the surrounding they are exposed to. For example, Raja \& Selvi (n.d) found that environmental challenges effects on the English language learners. There are numerous challenges faced by students from other parts of the world. Sudanese university students have problems in learning the English language, as an example, lack of motivation and teaching methods (Mohammed, n.d). Wold (2006) managed to obtain the internal struggles of students learning English. The students experience language anxiety as it is not their mother tongue and they lack in motivation.

The most defined perception is as the process of recognizing (being aware of), organizing (gathering and storing), and interpreting (binding to knowledge) sensory information. Perception deals with the human senses that generate signals from the environment through sight, hearing, touch, smell and taste which basically is the process interpreting the world around, sculpting a mental representation of the environment (Ward, Grinstein \& Keim, n.d).

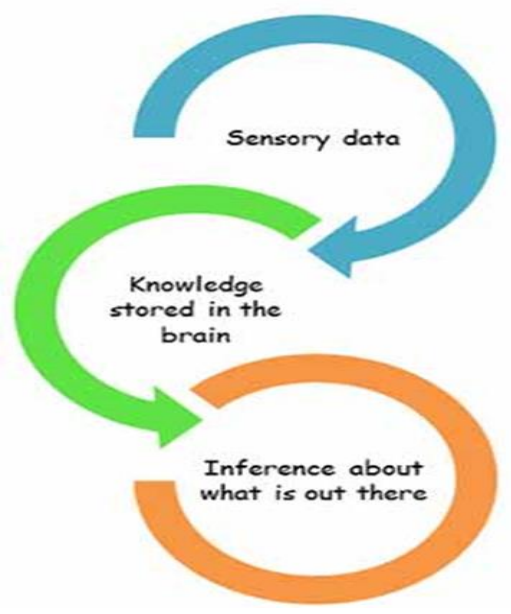

Figure 1: Top-down Processing (McLeod, 2008)

In the application of English Language, learners are referring to how the students perceived the language. One of the approaches of perception that is related to this research is the top down processing. The Top-down processing theory involves prior knowledge in interpreting perceptual information (Psychology concept, 2017). Sensory data must be organized by cognitive apparatus and then interpreted on the basis of available knowledge. (Demuth, 2013). According to Demuth (2013), under the constructivist theory, perception is the product of the contact between stimulus and internal hypotheses, expectations and knowledge of the 
observer. Motivation and emotions also play an important role in this process (Demuth, 2013) 'Perception is influenced by a lot of factors that can lead to inaccurate interpretation. (Eysenck, Keane, 2008, 74)' as noted by Demuth (2013). One of the theories under it is Gregory theory. The focus of this theory is previous experiences. According to Gregory (1990), the data obtained have the past and the future that changes and they influence each other. They have some hidden characteristics that will appear only if it is influenced by various conditions (Demuth, 2013). Gregory as stated by Demuth (2013) is suggesting that it is important in the vagueness of sensory data. He agrees on Gibson on the matter importance in receptors to acquire data but reject the idea of sensors could 'read' the meaning of certain data. Gregory believes this process, requires higher cortex centres activity and learning. Perception is a matter of receptors as well as of brain (Demuth, 2013). Information gathered by sensory organs is quite broad, that is why higher cognitive functions is needed to interpret them (Demuth, 2013).

\section{Past Related Studies}

A research was conducted to investigate employers' views of communication skill and English proficiency (Su, Marzuki, Kee, Misieng \& Jerome, 2017). The researchers discovered that employers perceive communication skill and English proficiency very seriously when hiring people. These skills are significance to the flow of work in the organization. Wijewardene, Yong \& Chinna (2014) noted employability defines a person with a set of skills and knowledge that makes an individual to secure a chosen occupation that will benefit themselves, the workforce, the community and the economy. English, which is an international language, plays an important role as a tool of communication locally and globally. Therefore, it is vital for graduates to be skilled in English to increase the chances of employment opportunities. Besides that, graduates will be able to use and communicate through the internet, with foreigners, and increase their knowledge as they travel places in expanding experiences (Wijewardene, Yong \& Chinna, 2014).

A study by Ridwan Wahid \& Zahariah Pilus (2017) was conducted in an interview to explore student experiences in learning and using English. They described their perception, problems, future plans and other issue using the English language. Another study by Abdul Kadir \& Mohd Noor (2015) utilized interview method through two focus groups. The second method is quantitative research using questionnaire or surveys that collects numeric data and is analysed with statistical techniques (Heigham \& Croker, 2009). Ibrahim et al. (2013) carried out a quantitative research by using questionnaire that resulted on the students' perception and barriers towards English language proficiency. Another example of quantitative research is by Singh (2014), applying questionnaire that proved students perception on English language learning is positive as it is vital for their future. The merge of qualitative and quantitative is called a mixed method. The data collected is from both methods to find a connection at one or several point within the study. This method found the cause of student's lack of English-speaking skill (Whai \& Leong, 2015) and also determine their perception the English-speaking skill (Rajprasit, Pratoomrat \& Wang, 2015).

\section{Methodology}

The current research applied mixed method. The mixed method is the mixing of qualitative and quantitative. This is to understand the research more completely (Creswell, 2008), noted by Heigham \& Croker (2009). The research was carried out in Universiti Tunku Abdul Rahman Kampar and the areas of Kampar. Choosing mixed methods research will combine 
the strengths of each methodology and reduces the weaknesses (Creswell \& Plano Clark, 2007). Researchers have claimed mixed methods research provides a more balanced perspective (Morse \& Chung, 2003).

\begin{tabular}{|l|l|l|}
\hline \multicolumn{2}{|c|}{ Mixed Method } \\
\hline Methods & Instruments & Data analysis \\
\hline Quantitative & $\begin{array}{l}\text { Survey Questions } \\
\text { The survey question adapts } \\
\text { Likert scale }\end{array}$ & $\begin{array}{l}\text { The data was analyzed with } \\
\text { SPSS }\end{array}$ \\
\hline Qualitative & $\begin{array}{l}\text { Interview } \\
\text { The interview questions will } \\
\text { ask on challenges faced by } \\
\text { development of English } \\
\text { communication. }\end{array}$ & $\begin{array}{l}\text { The data was analyzed to find } \\
\text { connections. } \\
\text { conne }\end{array}$ \\
\hline \multicolumn{2}{|l|}{ Compare and contrast the data } \\
\hline
\end{tabular}

Figure 2: Methodological Framework

Only 50 students were chosen to participate in the research. The students were chosen in order to see the effectiveness from various faculties in answering the questionnaire given. Therefore, there were 50 sets of questionnaires distributed and, in the end, as for data analysis, all 50 sets of questionnaires were used in analyzing the data needed.

The objectives of this study is to identify:

1. The perceptions of undergraduate students on the importance of English Language speaking skill.

2. The challenges faced by undergraduate students on their development of their English communication.

The main questions that were generated for this study were:

1. What are the perceptions of the Universiti Tunku Abdul Rahman? Undergraduate students on the importance of English language speaking skill?

2. What are the challenges faced by Universiti Tunku Abdul Rahman? Undergraduate students on their development of their English communication?

\section{Findings and Discussion}

The survey involved 50 undergraduate students in Universiti Tunku Abdul Rahman (UTAR), Perak, Malaysia where random sampling and convenience sampling were used among the entire undergraduate students of Universiti Tunku Adul Rahman as random sampling represent the total population to allow equal contributions and also convenience sampling targeted participants were at a close proximity of the researcher. Responses from the participants are shown below. 
The Perceptions of Undergraduate Students on The Importance of English Language Speaking Skill

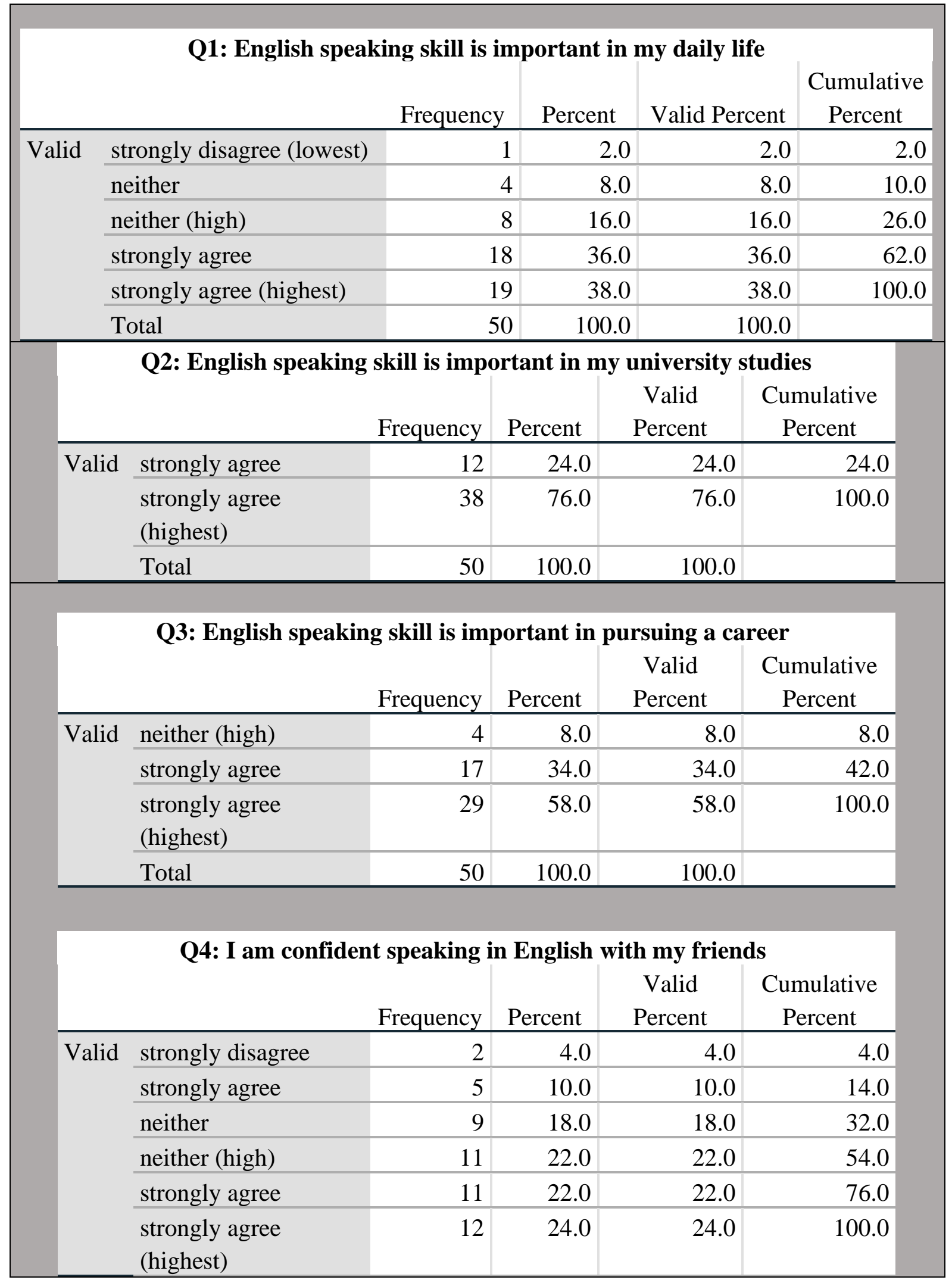




\begin{tabular}{|c|c|c|c|c|c|}
\hline \multicolumn{2}{|r|}{ Total } & 50 & 100.0 & 100.0 & \\
\hline \multicolumn{6}{|c|}{ Q5: I have sufficient English speaking skill } \\
\hline & & Frequency & Percent & $\begin{array}{c}\text { Valid } \\
\text { Percent }\end{array}$ & $\begin{array}{c}\text { Cumulative } \\
\text { Percent }\end{array}$ \\
\hline \multirow[t]{7}{*}{ Valid } & strongly disagree & 2 & 4.0 & 4.0 & 4.0 \\
\hline & strongly disagree & 7 & 14.0 & 14.0 & 18.0 \\
\hline & neither & 12 & 24.0 & 24.0 & 42.0 \\
\hline & neither (high) & 16 & 32.0 & 32.0 & 74.0 \\
\hline & strongly agree & 8 & 16.0 & 16.0 & 90.0 \\
\hline & $\begin{array}{l}\text { strongly agree } \\
\text { (highest) }\end{array}$ & 5 & 10.0 & 10.0 & 100.0 \\
\hline & Total & 50 & 100.0 & 100.0 & \\
\hline
\end{tabular}

\begin{tabular}{|l|r|r|r|r|}
\hline \multicolumn{2}{c}{ Q6: I find English speaking is difficult } \\
& Frequency & Percent & $\begin{array}{c}\text { Valid } \\
\text { Percent }\end{array}$ & $\begin{array}{c}\text { Cumulative } \\
\text { Percent }\end{array}$ \\
\hline Valid & 3 & 6.0 & 6.0 & 6.0 \\
\hline $\begin{array}{l}\text { strongly disagree } \\
\text { (lowest) }\end{array}$ & 6 & 12.0 & 12.0 & 18.0 \\
\hline strongly disagree & 5 & 10.0 & 10.0 & 28.0 \\
\hline strongly disagree & 2 & 4.0 & 4.0 & 32.0 \\
\hline neither & 10 & 20.0 & 20.0 & 52.0 \\
\hline neither (high) & 13 & 26.0 & 26.0 & 78.0 \\
\hline strongly agree & 11 & 22.0 & 22.0 & 100.0 \\
\hline strongly agree (highest) & 50 & 100.0 & 100.0 & \\
\hline Total & & & & \\
\hline
\end{tabular}

Q7: I do not have enough lessons to improve my English-speaking skill

\begin{tabular}{|c|c|c|c|c|c|}
\hline & & Frequency & Percent & $\begin{array}{c}\text { Valid } \\
\text { Percent }\end{array}$ & $\begin{array}{c}\text { Cumulative } \\
\text { Percent }\end{array}$ \\
\hline \multirow[t]{8}{*}{ Valid } & strongly disagree & 5 & 10.0 & 10.0 & 10.0 \\
\hline & strongly disagree & 4 & 8.0 & 8.0 & 18.0 \\
\hline & strongly disagree & 3 & 6.0 & 6.0 & 24.0 \\
\hline & neither & 9 & 18.0 & 18.0 & 42.0 \\
\hline & neither (high) & 16 & 32.0 & 32.0 & 74.0 \\
\hline & strongly agree & 9 & 18.0 & 18.0 & 92.0 \\
\hline & $\begin{array}{l}\text { strongly agree } \\
\text { (highest) }\end{array}$ & 4 & 8.0 & 8.0 & 100.0 \\
\hline & Total & 50 & 100.0 & 100.0 & \\
\hline
\end{tabular}




\begin{tabular}{|c|c|c|c|c|c|}
\hline \multicolumn{6}{|c|}{ Q8: I am not confident speaking English during presentation } \\
\hline & & Frequency & Percent & $\begin{array}{c}\text { Valid } \\
\text { Percent }\end{array}$ & $\begin{array}{c}\text { Cumulative } \\
\text { Percent }\end{array}$ \\
\hline \multirow[t]{8}{*}{ Valid } & strongly disagree & 7 & 14.0 & 14.0 & 14.0 \\
\hline & strongly disagree & 6 & 12.0 & 12.0 & 26.0 \\
\hline & strongly disagree & 6 & 12.0 & 12.0 & 38.0 \\
\hline & neither & 5 & 10.0 & 10.0 & 48.0 \\
\hline & neither (high) & 4 & 8.0 & 8.0 & 56.0 \\
\hline & strongly agree & 12 & 24.0 & 24.0 & 80.0 \\
\hline & $\begin{array}{l}\text { strongly agree } \\
\text { (highest) }\end{array}$ & 10 & 20.0 & 20.0 & 100.0 \\
\hline & Total & 50 & 100.0 & 100.0 & \\
\hline
\end{tabular}

\begin{tabular}{|c|c|c|c|c|c|}
\hline & Q9: I have no m & tion to impr & ve my En & ish speakin & skill \\
\hline & & Frequency & Percent & $\begin{array}{c}\text { Valid } \\
\text { Percent }\end{array}$ & $\begin{array}{c}\text { Cumulative } \\
\text { Percent }\end{array}$ \\
\hline Valid & strongly disagree & 8 & 16.0 & 16.0 & 16.0 \\
\hline & strongly disagree & 6 & 12.0 & 12.0 & 28.0 \\
\hline & strongly disagree & 11 & 22.0 & 22.0 & 50.0 \\
\hline & neither & 4 & 8.0 & 8.0 & 58.0 \\
\hline & neither (high) & 11 & 22.0 & 22.0 & 80.0 \\
\hline & strongly agree & 7 & 14.0 & 14.0 & 94.0 \\
\hline & $\begin{array}{l}\text { strongly agree } \\
\text { (highest) }\end{array}$ & 3 & 6.0 & 6.0 & 100.0 \\
\hline & Total & 50 & 100.0 & 100.0 & \\
\hline
\end{tabular}

\begin{tabular}{|l|r|r|r|r|}
\hline \multicolumn{2}{|c|}{ Q10: I become nervous speaking in English } \\
& Frequency & Percent & $\begin{array}{c}\text { Valid } \\
\text { Percent }\end{array}$ & $\begin{array}{c}\text { Cumulative } \\
\text { Percent }\end{array}$ \\
\hline Valid & 6 & 12.0 & 12.0 & 12.0 \\
\begin{tabular}{ll|r|r|r} 
strongly disagree \\
(lowest)
\end{tabular} & 7 & 14.0 & 14.0 & 26.0 \\
\hline strongly disagree & 5 & 10.0 & 10.0 & 36.0 \\
\hline strongly disagree & 1 & 2.0 & 2.0 & 38.0 \\
\hline neither & 9 & 18.0 & 18.0 & 56.0 \\
\hline neither (high) & 14 & 28.0 & 28.0 & 84.0 \\
\hline strongly agree & 8 & 16.0 & 16.0 & 100.0 \\
\hline strongly agree (highest) & 50 & 100.0 & 100.0 & \\
\hline Total & & &
\end{tabular}


The result on the perceptions of Undergraduate students on the importance of English Language speaking skill shows that the highest percentage is strongly agree (highest) which is $38 \%$ as it shows a drastic difference. The second question, however, only shows two percentages, which are strongly agree (highest) with $76 \%$ and strongly agree with $24 \%$. The third question shows the percentage in strongly agree (highest) with 58\% where obvious difference is highlighted. The fourth question showed the highest percentage in strongly agree (highest), with 24\%, nonetheless, neither (high) and strongly agree shows little difference that is $22 \%$. The fifth question has the highest percentage in neither (highest) with $32 \%$ and the lowest percentage is $4 \%$ in strongly disagree (lowest). The sixth question shows strongly agree as the highest percentage with $26 \%$. There is minor difference from the highest percentage, and it shows in strongly agree (highest) with $22 \%$ and neither (high) $20 \%$. The seventh question shows neither (high) with $32 \%$ as the highest percentage and the other percentages shows below 20\%. The eighth question highest percentage is $24 \%$ under strongly agree with second highest percentage of $20 \%$ under strongly agree (highest). The ninth question show $22 \%$ as the highest percentage that is under strongly disagree (high) and neither (high). The tenth question shows strongly agree of $28 \%$ and strongly agree (highest) $16 \%$.

The results from the questionnaire gained a number of high percentages that indicates the students understand that English Language speaking skill is significant for their life. This is because; it is a tool of communication in university for learning. Not only that, from the questionnaire, the students known it is important to have the ability to speak English for when they go out to apply for a job. Most organizations now seek for graduates who are able to speak the English language as it helps with negotiations with overseas company. The questionnaire also found the participants perceived that English language as difficult. This is shown in the interview data. Some of the results that is 'strongly agree' is signifying the students' self-esteem and emotion. The students have little confidence in themselves to speak in English. They fear being judged of their inadequacy and sense of nervousness will take over. One of the results is on the students' motivation to improve their English that share the same percentage which is $22 \%$ under 'strongly disagree (high)' and neither (high). This is because, some of the students still have the willingness to develop English language speaking skill. However, for some, they are uncertain or have motivations on certain occasion. The result of 'neither (high)' of $32 \%$ is the perception of students not having enough lessons to improve their English-speaking skill that imply they have the means to get better at speaking English, although there are other factors influence the decision.

\section{The Challenges Faced by Undergraduate Students on Their Development of Their English Communication}

The first interview question that was asked is 'Does your mother tongue /national language interfere with your English-speaking skill? If yes, why?' The results that show 'Yes', the participants agree that their mother tongue or national language contributes a slow process of picking up the English-speaking skill. They would use Manglish (Malay+English), Tanglish (Tamil+English), Chinglish (Chinese+English). They experience the direct translation from their mother tongue/ national language to English Language. The result that show 'No', the participants does not experience difficulties in the languages as they could 'code-switch well'. They have adequacy in the languages. 
The second interview question is 'What other challenges you face in speaking in English apart from using your mother tongue/national language?' This question has obtained a number of results. The participants found that pronunciation is one of the main struggles speaking in English. One of the participants have the trouble in pronouncing the words with the letter ' $\mathrm{S}$ '. Most of the participants that mention pronunciation as a challenge also stated that lack of vocabulary is a hindrance to their English-speaking skill. Besides that, the participants listed down what they are lacking, as challenges they face speaking in English, such as lack of knowledge, lack of communication and lack of confidence. Other challenges also come from their fear of judgment and they are afraid of making grammar error. They find English language is difficult to speak as some stutter and brings them to speak with no sense. The participants have translation problem between the languages for some reason such as sentence structures. They would give the direct translation from their mother tongue/national language which were not always right. Some gets confused and frustrated as some words in the English language is the same. The participants would also go through the obstacles of speaking with other people and the listener could not understand, some even stated it as due to speaking too fast and clashing of meaning or accent because of not the same level of English-speaking skill.

The third interview question is 'What are the ways you have used or currently using in improving your English-speaking skill in university?' The results obtained were leaning towards electronic media because the participants stated that they watch YouTube videos on commencement speeches, debate and public speaking. Besides that, they watch English movies and TV shows as they could imitate how the native English speaker would speak English. They would also listen to podcasts and English music. The participants read English materials from storybooks, magazines and newspapers and they would look up for English meanings and listen to the pronunciation. Also, they try to speak more in English to their friends, especially the international students and to the lecturers as well.

The pattern could be seen from the results obtained from the interview questions. Most agrees that their mother tongue/national language interferes with their English language speaking skill. Apart from it, the common results highlighted in the second interview questions were the pronunciation, lack of confidence and fear of judgment. The results in the third question focused towards electronic media which is watching YouTube, television shows, movies and listening to music.

The questionnaire and interviews exhibited positive results. In questionnaire, the results showed that the participants have strong belief that English-speaking skill is important. They agree English speaking skill is important in their daily life as they use it with their friends, in university and also for their career. In spite of the fact, there are challenges they experienced. In the questionnaire, the results were found that the participants strongly agreed that English Language speaking skill is difficult. This is because, as from the interviews, participants' mother tongue/national language hinders their development of English-speaking skill that impedes their pronunciation. The participants' perception on their self-esteem about their English language speaking skill supports the results from the interviews. The participants do not have enough confidence to speak in English and also, they are fear of other's judgment on how they speak the language confidently. 


\section{Conclusion and Recommendations}

The current research reported that students perceive English language speaking skill as an importance for personal and professional life. However, the challenges they experienced does not affect their perceptions. The main obstacles faced are pronunciation, lack in confidence and fear of judgment. Students have managed to find ways to develop their English-speaking skill, which is by turning to electronic media. The students are trying to improve as they understand that the English language is important. In helping students to improve their English-speaking skills, the approach should be more enjoyment and trending. Besides that, games or events that uses songs or movies references should be organized to enhance the usage of English language among students. However, the traditional way should not also be forgotten as some students would still prefer to use the books in enhancing their language skills. Therefore, it is vital for the government and universities to take action for the students to speak better in the English Language as they will be considered and accepted for the jobs they apply once they move into the global workforce. In conclusion, in-depth future research in the topic of perceptions and challenges on English Language speaking skill can be carried out in detail among other universities in Malaysia to highlight the issues on perceptions and challenges of undergraduates' on their English language speaking skills and thus, create a pathway in enhancing the skill for more undergraduates to speak and master their speaking skills.

\section{References}

Abdul Kadir, K \& Mohd Noor, W.S.W (2015) Students' Awareness of the Importance of English Language Proficiency With Regard to Future Employment. World Review of Business Research. Volume 5. Retrieved from http://www.wrbrpapers.com/static/documents/September/2015/18.\%20Kadzrina.pdf

Alias, N. Z. (2017) My Say: Making graduates more employable. The Edge Markets: Make Better Decisions. Retrieved from http://www.theedgemarkets.com/article/my-say-making-graduates-more-employable

Al Nakhalah, A.M.M. (2016) Problems and Difficulties of Speaking That Encounter English Language Students at Al Quds Open University. International Journal of Humanities and Social Science Invention. Volume 5 (Issue 12). Retrieved from http://www.ijhssi.org/papers/v5 (12)/version-3/O5120396101.pdf

Bottom-up and Top-down Processing (2017). Psychology Concepts. Retrieved from URL http://www.psychologyconcepts.com/bottom-up-and-top-down-processing/

Creswell, J.W. (2009). Research Design: Qualitative, Quantitative, and Mixed Methods Approaches Retrieved from http://www.ceil-conicet.gov.ar/wpcontent/uploads/2015/10/Creswell-Cap-10.pdf

Darmi, R. \& Albion, P.R (2015, July 8). English Language in Malaysian Education System: Its Existence and Implication. Paper presented at 2nd Malaysian Postgraduate Conference.

Heigham, J \& Croker, R.A (2009). Qualitative Research in Applied Linguistics. United Kingdom: Palgrave Macmillan

Ibrahim, Z.S., Hassali, M.A, Saleem, F., Ul Haq, N., Khan, T.M. \& Aljadhey, H. (2013). Perceptions and barriers towards English language proficiency among pharmacy undergraduates at Universiti Sains Malaysia. Pharmacy Education. Retrieved from http://pharmacyeducationjournal.org/pharmacyeducation/article/view/212/185. 
McLeod, S. (2008). Visual Perception Theory. Simply Psychology. Retrieved from https://www.simplypsychology.org/perception-theories.html

Misbah, N. H., Mohamad, M., Md Yunus, M., \& Ya'acob, A. (2017). Identifying the Factors Contributing to Students' Difficulties in the English Language Learning. Creative Education, 8, 1999-2008. Retrieved from https://doi.org/10.4236/ce.2017.813136

Leong, L.M. \& Ahmadi, S.M. (2017). An Analysis of Factors Influencing Learners' EnglishSpeaking Skill. International Journal of Research in English Education. Retrieved from http://ijreeonline.com/article-1-38-en.pdf

Singh, M.K.M (2014). Undergraduates' Perception of the English Language Proficiency Course at Tertiary Level. International Journal of Humanities and Social Science. Retrieved from http://www.ijhssnet.com/journals/Vol_4_No_12_October_2014/21.pdf

Su, H.T., Marzuki, E., Kee, M.C., Misieng, J. \& Jerome, C. (2017). Employers' Views on the Importance of English Proficiency and Communication Skill for Employability in Malaysia. Indonesian Journal of Applied Linguistics, Vol.7. Retrieved from https://www.researchgate.net/publication/320133549_Employers'_Views_on_Importa nce_of_English_Proficiency_and_Communication_Skill_for_Employability_in_Mala ysia

The Malaysian Times: English language and its importance to Malaysia's growth (2012). Rationalizing You. Retrieved from http://www.themalaysiantimes.com.my/englishlanguage-and-its-importance-to-malaysia\%E2\%80\%99s-growth/

The Star Online. English proficiency still a big problem for many M'sian grads (2017). Retrieved from https://www.thestar.com.my/news/nation/2017/01/21/englishproficiency-still-a-big-problem-for-many-msian-grads/

Ward, M.O., Grinstein, G \& Keim, D. (n.d) Interactive Data Visualization: Foundation, Techniques and Applications. Retrieved from https://books.google.com.my/books?id=XHZ3CAAAQBAJ\&pg=PA82\&lpg=PA82\& $\mathrm{dq}=$ 